\title{
A Review on Underlying Differences in the Prevalence of Metabolic Syndrome in the Middle East, Europe and North America
}

\author{
Mohsen Nematy ${ }^{1}$, Farnaz Ahmadpour ${ }^{1}$, Zahra Behnam Rassouli ${ }^{1}$, Hosein Mohaddes Ardabili ${ }^{1}$ and Mohsen Azimi-Nezhad ${ }^{2,3^{*}}$ \\ ${ }^{1}$ Department of Nutrition, School of Medicine, Biochemistry and Nutrition, Endoscopic \& Minimally Invasive Surgery, and Cancer Research Centers, Mashhad University \\ of Medical Sciences (MUMS) Mashhad, Iran \\ ${ }^{2}$ Department of Medical Genetics, School of Medicine, Mashhad University of Medical Sciences (MUMS) Mashhad, Iran \\ ${ }^{3}$ Research Unit "Gene-Environment Interactions in Cardiovascular Pathophysiology" University of Lorraine, UMR INSERM U 1122, IGE-PCV, Nancy, France \\ "Corresponding author: Mohsen Azimi-Nezhad, Department of Medical Genetics, School of Medicine, Mashhad University of Medical Sciences (MUMS) Mashhad, \\ Iran, Tel: +985118827046; Fax: +985118827051; Email: aziminm@mums.ac.ir \\ Received date: December 16, 2013; Accepted date: February 17, 2014; Published date: February 20, 2014 \\ Copyright: (02014 Azimi-Nezhad M, et al. This is an open-access article distributed under the terms of the Creative Commons Attribution License, which permits \\ unrestricted use, distribution, and reproduction in any medium, provided the original author and source are credited.

\begin{abstract}
Increasing burden of obesity, the metabolic syndrome (MetS), Type 2 Diabetes Mellitus (T2DM), and CardioVascular Diseases (CVD) in developing countries has created an urgent need for more researches on the various factors responsible for increasing their prevalence. Literature search was carried out using the terms obesity, insulin resistance, diabetes, dyslipidemia, physical inactivity, the metabolic syndrome, and developing countries, in order to review the criteria and risk factors of MetS and its prevalence in Middle East countries from web sites and published documents. The prevalence of the syndrome and its underlying factors was also compared between some of the Middle East and some of European and American countries. The pattern of the components of metabolic syndrome varies in the Middle East region in comparison with Europe and North America. In addition to differences of diet behaviors, the genetic factors and some of geographic dependent elements may influence the variation of metabolic syndrome architecture worldwide particularly in the Middle East region.
\end{abstract}

\section{Introduction}

Increasing burden of obesity, MetS, T2DM, and CVD in developing countries has created an urgent need for more researches on the various factors responsible for increasing their prevalence [1-4]. MetS has generated much concern over the past few years because it clearly represents a high risk for developing diabetes type 2 and cardiovascular diseases. Hypertriglyceridemia, obesity, insulin resistance, glucose intolerance, hypertension, and physical inactivity are the main risk factors of MetS [5-7], but its association with other interrelated factors is still unknown.

Although it's suggested that the improvement of economic situation, nutrition transition, and increased urbanization in developing countries play the important roles in increasing prevalence of obesity and the MetS [1,8-13], more researches is needed to confirm these suggestions. Greater efforts are also needed to properly diagnose other affecting environmental and genetic factors in order to find out the basic mechanisms which lead to the susceptibility of individuals to the MetS [14-17]. It is well documented now that the prevalence of metabolic syndrome is increasing worldwide. However, it seems that not only its prevalence in some geographic regions and ethnic groups is higher than others but also the patterns of its related components are widely different [18].

In this article, we reviewed the criteria and risk factors of MetS and then discussed its prevalence in the Middle East countries. After that we compared the prevalence of the syndrome and its underlying factors between some of the Middle East and some of the European countries and finally discussed in brief about other probably influencing factors on metabolic syndrome or its related components.

\section{Clinical Diagnosis of Metabolic Syndrome}

Different organizations have recommended clinical criteria for the diagnosis of the MetS (Table 1). There is general consensus regarding the main components of the syndrome (glucose intolerance, obesity, raised blood pressure and dyslipidaemia [elevated triglycerides, low levels of high density lipoprotein cholesterol]) but different definitions also reveal fundamental differences in positioning of the predominant causes of the syndrome, for example obesity in men using the World Health Organization (WHO) definition requires body mass index (BMI) $>30 \mathrm{~kg} / \mathrm{m}^{2}$ or waist:hip ratio $>9.0$, whereas the waist circumference is required by the National Cholesterol Education Program (NCEP) $(>102 \mathrm{~cm})$, European Group for the study of Insulin Resistance (EGIR) and International Diabetes Federation (IDF) (>94 cm) [19-22].

The World Health Organization (WHO), the National Cholesterol Education Program-Adult Treatment Panel III (NCEP-ATP III) and the International Diabetes Federation (IDF), have recognized the MetS as a major CVD risk factor $[7,23]$.

\section{World health organization (WHO) definition}

The first attempt at a global definition of the MetS was by WHO [24] (Table 1). Primary to the WHO definition was the biological and physiological description of insulin resistance (measured by the euglycaemic clamp, a method for the quantification of tissue sensitivity to insulin) $[7,19,21,22,25]$. Insulin resistance was defined as 1 of the following: type 2 diabetes; impaired fasting glucose (IFG); impaired glucose tolerance (IGT), or for those with normal fasting glucose values $(<110 \mathrm{mg} / \mathrm{dL})$, a glucose uptake below the lowest quartile for background population under hyperinsulinemic, 
Citation: $\quad$ Nematy M , Ahmadpour F, Rassouli ZB, Ardabili HM, Azimi-Nezhad M (2014) A Review on Underlying Differences in the Prevalence of Metabolic Syndrome in the Middle East, Europe and North America. J Mol Genet Med S1: 019. doi:10.4172/1747-0862.S1-019

Page 2 of 12

euglycemic conditions [19]. In addition to insulin resistance, two other risk factors are sufficient for the diagnosis of MetS (Table 1) [22].

The most important limitation of WHO criteria was related to the use of the euglycaemic clamp, making the definition practically impossible to use in either clinical practice or epidemiological studies $[20,22]$.

\section{European group for studying insulin resistance (EGIR) definition}

EGIR relied on fasting insulin instead of the euglycaemic clamp to measure insulin resistance [21,26] (Table 1). The EGIR believed that insulin resistance was the underlying cause of the MetS, but restricted the use of the definition to those in whom insulin resistance could be easily and reliably measured. Hence, people with diabetes were excluded from the definition [20,22]. The EGIR definition also introduced waist circumference EGIR $(94 \mathrm{~cm}$ for men and $80 \mathrm{~cm}$ for women) as the measure of adiposity and included modified cut points for hypertension, triglycerides (TGs), high-density lipoprotein (HDL) cholesterol [21,22].

\section{National cholesterol education program (NCEP) definition}

The NCEP/ATPIII designed to have clinical utility (Table 1). Its definition did not include a specific measure of insulin sensitivity, and adopted a less 'glucose-centric' approach by treating all components with equal importance [22,27]. Notably, it retained waist circumference as the measure of obesity (although with higher cutpoints than EGIR (102 cm for men and $88 \mathrm{~cm}$ for women)) [21].

The 6 components of the MetS identified by ATP III are: abdominal obesity, atherogenic dyslipidemia, raised blood pressure, insulin resistance, glucose intolerance, proinflammatory state, and prothrombotic state, which are easily and routinely measured in most clinical and research settings $[19,20]$. These components are the combination of what ATP III terms underlying (obesity, physical inactivity, and atherogenic diet), major (cigarette smoking, hypertension, elevated LDL cholesterol, low HDL cholesterol, family history of premature coronary heart disease (CHD), and aging), and emerging (elevated triglycerides, small LDL particles, insulin resistance, glucose intolerance, proinflammatory state, and prothrombotic state) risk factors for CVD [19].

\section{American association of clinical endocrinology (AACE) definition}

AACE is a modification of the ATPIII definition, based on the belief that insulin resistance is the core feature [28]. There are four factors as 'identifying abnormalities' of the MetS in AACE criteria: elevated triglycerides, reduced HDL-C, elevated blood pressure, and elevated fasting and post load glucose [20,22]. Factors which increase the likelihood of the syndrome rather than as key identifying abnormalities are listed as obesity, diagnosis of hypertension, gestational diabetes or CVD or family history of diabetes, hypertension, non-European ancestry or age greater than 40 years and a sedentary lifestyle [20]. The AACE statement deliberately does not provide a specific definition of the syndrome so the diagnosis was allowed to rely on clinical judgment [22].

\section{International diabetes federation (IDF) definition}

The IDF is a useful definition for clinicians to identify which persons are at risk of type 2 diabetes and CVD [20]. It also facilitates epidemiological and clinical research into the MetS [22]. Central obesity is an important determinant of the MetS by the IDF group and they recognized that there is a strong association between waist circumference, CVD and other component of the MetS (Table 1). Visceral fat accumulation determined by CT scan has been demonstrated to have close correlation with the development of metabolic and CVD, so it is placed in pivotal position of the new definition and an essential component [20].

The IDF Consensus group have recommended cut points for central obesity based on waist circumference which are applicable to individual ethnic groups (Table 1) [21,22]. It was also decided that the definition should be less 'glucose-centric'. Moreover insulin resistance was omitted as a component as other components such as waist circumference and triglycerides are so highly correlated with insulin resistance [29], so few of those with insulin resistance would be missed.

The thresholds of other components were similar to those used in the ATPIII except for glucose, where the cutoff of $5.6 \mathrm{mmol} / \mathrm{l}(100$ $\mathrm{mg} / \mathrm{dl}$ ) recommended by the American Diabetes Association was adopted for impaired fasting glucose [20].

\begin{tabular}{|c|c|c|c|c|c|}
\hline Clinical measure & IDF(2005) & $\operatorname{NCEP}(2001)$ & WHO(1998) & EGIR & AACE \\
\hline Insulin resistance & None & $\begin{array}{l}\text { None, } \\
\text { but any } 3 \text { of the following } \\
5 \text { features }\end{array}$ & $\begin{array}{l}\text { IGT, IFG, T2DM, or lowered insulin } \\
\text { sensitivity* } \\
\text { plus any } 2 \text { of the following }\end{array}$ & $\begin{array}{l}\text { Plasma insulin }>75 \text { th } \\
\text { percentile } \\
\text { plus any } 2 \text { of the following }\end{array}$ & $\begin{array}{l}\text { IGT or IFG } \\
\text { plus any of the } \\
\text { following based on } \\
\text { clinical judgment }\end{array}$ \\
\hline Body weight & $\begin{array}{l}\text { Increased WC (population } \\
\text { specific) plus any } 2 \text { of the } \\
\text { following }\end{array}$ & $\begin{array}{l}W C \geq 102 \mathrm{~cm} \text { in men or } \geq \\
88 \mathrm{~cm} \text { in women }\end{array}$ & $\begin{array}{l}\text { Men: waist-to-hip ratio }>0.90 \text {; } \\
\text { women: waist-to-hip ratio }>0.85 \\
\text { and/or BMl }>30 \mathrm{~kg} / \mathrm{m}^{2}\end{array}$ & $\begin{array}{l}W C \geq 94 \mathrm{~cm} \text { in men or } \geq \\
80 \mathrm{~cm} \text { in women }\end{array}$ & $\mathrm{BMI} \geq 25 \mathrm{~kg} / \mathrm{m}^{2}$ \\
\hline Lipid & $\begin{array}{l}\text { TG } \geq 150 \quad \text { or on } \\
\text { TG Rx } \\
\text { HDL-C }<40 \mathrm{mg} / \mathrm{dL} \text { in men } \\
\text { or }<50 \mathrm{mg} / \mathrm{dL} \text { in women } \\
\text { or on HDL-C Rx }\end{array}$ & $\begin{array}{l}\text { TG } \geq 150 \mathrm{mg} / \mathrm{dL} \\
\mathrm{HDL}- \\
\mathrm{C}: \\
\text { men or }<50 \mathrm{mg} / \mathrm{dL} \text { in } \\
\text { women }\end{array}$ & $\begin{array}{l}\mathrm{TG} \geq 150 \mathrm{mg} / \mathrm{dL} \text { and } / \mathrm{or} \\
\mathrm{HDL}-\mathrm{C}<35 \mathrm{mg} / \mathrm{dL} \text { in men or }<39 \\
\mathrm{mg} / \mathrm{dL} \text { in women }\end{array}$ & $\begin{array}{l}\mathrm{TG} \geq 150 \mathrm{mg} / \mathrm{dL} \text { and } / \mathrm{or} \\
\mathrm{HDL}-\mathrm{C}<39 \mathrm{mg} / \mathrm{dL} \text { in men } \\
\text { or women }\end{array}$ & $\begin{array}{l}\mathrm{TG} \geq 150 \mathrm{mg} / \mathrm{dL} \text { and } \\
\mathrm{HDL}-\mathrm{C}<40 \mathrm{mg} / \mathrm{dL} \text { in } \\
\text { men or }<50 \mathrm{mg} / \mathrm{dL} \text { in } \\
\text { women }\end{array}$ \\
\hline Blood pressure & $\begin{array}{l}\geq 130 \mathrm{~mm} \mathrm{Hg} \text { systolic or } \geq \\
85 \mathrm{~mm} \mathrm{Hg} \text { diastolic or on } \\
\text { hypertension } \mathrm{Rx}\end{array}$ & $\geq 130 / 85 \mathrm{~mm} \mathrm{Hg}$ & $\geq 140 / 90 \mathrm{~mm} \mathrm{Hg}$ & $\begin{array}{l}\geq 140 / 90 \mathrm{~mm} \mathrm{Hg} \text { or on } \\
\text { hypertension } \mathrm{Rx}\end{array}$ & $\geq 130 / 85 \mathrm{~mm} \mathrm{Hg}$ \\
\hline
\end{tabular}


Citation: $\quad$ Nematy M , Ahmadpour F, Rassouli ZB, Ardabili HM, Azimi-Nezhad M (2014) A Review on Underlying Differences in the Prevalence of Metabolic Syndrome in the Middle East, Europe and North America. J Mol Genet Med S1: 019. doi:10.4172/1747-0862.S1-019

Page 3 of 12

\begin{tabular}{|c|c|c|c|c|c|}
\hline Glucose & $\begin{array}{l}\geq 100 \mathrm{mg} / \mathrm{dL} \text { (includes } \\
\text { diabetes) }\end{array}$ & $\begin{array}{l}>110 \mathrm{mg} / \mathrm{dL} \quad \text { (includes } \\
\text { diabetes) }\end{array}$ & IGT, IFG, or T2DM & $\begin{array}{l}\text { IGT or IFG (but not } \\
\text { diabetes) }\end{array}$ & $\begin{array}{l}\text { IGT or IFG (but not } \\
\text { diabetes) }\end{array}$ \\
\hline Other & & & $\begin{array}{l}\text { Microalbuminuria (urinary average } \\
\text { excretion rate } \geq 20 \mu \mathrm{g} / \mathrm{min} \text { or } \\
\text { albumin-creatinine ratio } \geq 20 \mathrm{mg} / \mathrm{g} \text { ) }\end{array}$ & & $\begin{array}{l}\text { Other features of } \\
\text { insulin resistance }\end{array}$ \\
\hline \multicolumn{6}{|c|}{$\begin{array}{l}\text { IDF: International Diabetes Federation; NCEP: National Cholesterol Education Program; WHO: World Health Organization; EGIR: European Group for Studying Insulin } \\
\text { Resistance; AACE: American Association of Clinical Endocrinology; IGT: Impaired Glucose Tolerance (2-h glucose } \geq 140 \mathrm{mg} / \mathrm{dL}) ; \text { IFG: Impaired Fasting Glucose (110 } \\
\leq \text { fasting glucose } \leq 126 \mathrm{mg} / \mathrm{dL}) ; \text { T2DM: Type } 2 \text { diabetes Mellitus; WC: Waist Circumference; BMl: Body Mass Index; TG: Triglycerides; HDL-C: High Density } \\
\text { Lipoprotein Cholesterol; Rx: Recommended Treatment }\end{array}$} \\
\hline \multicolumn{6}{|c|}{$\begin{array}{l}{ }^{1} \text { The } 2001 \text { definition identified fasting plasma glucose of } \geq 110 \mathrm{mg} / \mathrm{dL}(6.1 \mathrm{mmol} / \mathrm{L}) \text { as elevated. This was modified in } 2004 \text { to be } \geq 100 \mathrm{mg} / \mathrm{dL}(5.6 \mathrm{mmol} / \mathrm{L}) \text {, in } \\
\text { accordance with the American Diabetes Association's updated definition of IFG. }\end{array}$} \\
\hline \multicolumn{6}{|c|}{ 2IIncludes family history of T2D mellitus, polycystic ovary syndrome, sedentary lifestyle, advancing age, and ethnic groups susceptible to T2D mellitus. } \\
\hline
\end{tabular}

Table 1: Proposed Criteria for Clinical Diagnosis of the MetS

\section{Risk Factors}

Nutritionally-related pattern have changed considerably in the Middle East countries during recent years because of social development in the absence of steady economic growth and changes in dietary and physical activity pattern [30]. Bear all these facts in mind, the main risk factors of the MetS are the followings:

\section{Insulin resistance}

Insulin resistance, implying depressed cellular sensitivity to insulin [31], is present in the majority of people with the MetS which strongly associates with other metabolic risk factors and also CVD risk [32].

The Expert Committee on the Diagnosis and Classification of Diabetes Mellitus defines impaired fasting glucose as $>100 \mathrm{mg} / \mathrm{dL}$ (5.6 $\mathrm{mmol} / \mathrm{L})$ but $<126 \mathrm{mg} / \mathrm{dL}(7.0 \mathrm{mmol} / \mathrm{L})$ and impaired glucose tolerance as 2-hour oral glucose tolerance test values $>140 \mathrm{mg} / \mathrm{dL}$ (7.8 $\mathrm{mmol} / \mathrm{L})$ [33].

\section{Obesity}

"Obesity epidemic" is considered by ATP III as mainly responsible for the increasing prevalence of MetS [32]. Obesity has been strongly associated with insulin resistance [34], T2DM [35] and the MetS [36] and higher CVD risk [32]. Since there is a strong connection between abdominal obesity and metabolic risk factors, ATP III defined the MetS as a clustering of metabolic complications of obesity [32].

It is claimed that intra-abdominal fat and visceral adipose tissue are strongly associated with insulin resistance and therefore the MetS than other adipose tissue compartments [37,38]. It is noteworthy to mention that, several studies declared that subcutaneous truncal fat plays an important role in insulin resistance [39-42].

Researchers suggest that sensitivity of individuals to changes in body fat is genotype-dependent $[43,44]$. Some results identified quantitative trait loci with significant effects on adipocyte-derived protein and revealed the emergence of a consistent pattern of linkage results for obesity-related traits across a number of human populations [45]. Also it is suggested that genetic factors explain 50 to $90 \%$ of the variance in $\mathrm{BMI}$ in twins and estimates of parent-offspring and sibling correlations in agreement with heritabilities of 20 to $80 \%$ is generally reported [46]. Common genetic polymorphisms are important determinants of obesity $[47,48]$, such as the Trp64Arg variant in the Beta-3 adrenergic receptor gene and the Val103Ile variant in the MC4R receptor [49].
Among different countries in the Middle East region there is significant heterogeneity in obesity prevalence [50]. In Iran the prevalence of obesity was shown to be $22.3 \%$ among adults $(30.6 \%$ in females and $14.2 \%$ in males) [51]. In 2005, among urban Iranians aged $15-70$ years the prevalence rate was between $22 \%$ and $40 \%$ [52]. As reported in these studies, Iranian females have a higher prevalence of obesity compared to men. In other Middle East countries such as Saudi Arabia (24\% in females and $16 \%$ in males, age $\geq 15$ years) [53], Oman (23.8\% in females and $16.7 \%$ in males, age $\geq 20$ years) [54], Lebanon ( $18.8 \%$ in females and $14.3 \%$ in males, age $\geq 20$ years) [55] and Turkey ( $24.6 \%$ vs. $14.4 \%$ in males, age $\geq 20$ years) [56] the prevalence is higher in women the same as Iran.

\section{Hypertension}

Hypertension is listed among the MetS components [57]. It is the most important MetS risk factor that predisposes to increased cardiovascular morbidity and mortality [58]. Elevated blood pressure strongly associates with central obesity and insulin resistance $[32,59]$. In a worldwide survey, $26.4 \%$ of the adult population in 2000 had hypertension (26.6\% of men and $26.1 \%$ of women), and $29.2 \%$ were projected to have this condition by 2025 (29.0\% of men and $29.5 \%$ of women) [60]. The number of adults with hypertension in 2025 was predicted to increase by about $60 \%$ to a total of 1.56 billion [60]. In a survey done in Iran in 2007, the prevalence rate of hypertension was $26.6 \%$ (28.6\% in females and $24.7 \%$ in males) [51]. In 2003, the prevalence of hypertension in Turkey is $31.8 \%$ (36.1\% in females and $27.5 \%$ in males, age $\geq 18$ years) [61], which is higher than the rate in Iran. In another study done among a Turkish population, the prevalence of SBP $\geq 140 \mathrm{mmHg}$ was $12.0 \%$ and of DBP $\geq 90 \mathrm{mmHg}$ was $8.2 \%$ [62]. The age-adjusted prevalence of hypertension in Oman was shown to be $38.3 \%$ [63]. Subjects with impaired fasting glucose, diabetes, or hyperchlosteremia and obesity were more likely to have hypertension [63].

\section{Physical inactivity}

Changes of occupations, advent of newer technologies, and rapid pace of urban life have increasingly brought about more sedentary work and less energy expenditure [1]. Data from the World Health Survey (2002-2003) conducted in 51 countries, most of which were developing countries showed that about $15 \%$ of men and $20 \%$ of women were at risk for chronic diseases due to physical inactivity [64]. The prevalence of physical inactivity at less than the levels recommended for enhancing health is high in both developing (from 17 to $91 \%$ ) and developed countries (from 4 to $84 \%$ ) [65]. 
Page 4 of 12

Immigrant women from Iran and Turkey had higher prevalence of abdominal obesity, an unfavorable lipid profile, and a high degree of physical inactivity during leisure time compared with women born in Sweden which may predispose for a higher incidence of diabetes and atherosclerotic cardiovascular disease [66]. The mentioned study indicates important ethnic differences in cardiovascular disease risk factor pattern [66]. In Saudi Arabia, inactivity prevalence was very high $(96.1 \%)$ and women were more inactive than men $(98.1 \%$ vs. 93.9\%) [67]. It reveals that the majority of men and women in Saudi Arabia did not reach the recommended physical activity levels necessary for promoting health and preventing diseases [67].

In addition to sedentary life which has resulted in an epidemic of metabolic disorders and excessive body fat accumulation, it was demonstrated that the collective genome of the microorganisms inhabiting our body, known as the -microbiome- may have a great role in the pathogenesis of obesity given its direct interaction with environmental factors [68]. Individuals with a low bacterial richness were characterized by more marked overall adiposity, insulin resistance and dyslipidaemia and a more pronounced inflammatory phenotype when compared with high bacterial richness individuals $[68,69]$. Human microbiome varies among individuals depending on age, diet, and geographical distribution and has been linked with important human diseases, including inflammation-linked disorders, such as allergies, obesity, and inflammatory bowel disease [70,71]. The relative proportion of Bacteroidetes is decreased in obese people by comparison with lean people, which increases with weight loss on lowcalorie diets [72]. These reports indicated that the low glycemic index and rich fiber diets may influence the gene expression capacity of the gastrointestinal microbiome. It does not need, here to discuss about the probably microbiome gene mutations those could change the functions of the gene even in presence of mentioned healthy diets.

It was indicated that individual differences in habitual physical activity level are characterized by a significant genetic component [43]. Gene expression alterations by exercise deficiency contribute to morbidity and mortality, which highlights the importance of using the evolutionary pressures that have shaped human physiological responses to define better the functions for exercise-induced changes in gene expression in both physiological and pathophysiological conditions [73].

\section{Dyslipidemia}

Atherogenic dyslipidemia includes elevated serum triglyceride and apolipoprotein B (apoB), increased small LDL particles, and a reduced level of HDL cholesterol [74].

It's suggested that some genetic and environmental factors affect the prevalence of lipid abnormalities [75-77]. Strong single-gene effects are found for low-density lipoprotein (LDL) cholesterol, lipoprotein (a) (Lplal), low high-density lipoprotein (HDL) cholesterol, and high apolipoprotein (apo) B [78]. Kathiresan et al. [79] identified 30 distinct loci associated with lipoprotein concentrations (each with $\mathrm{P}<5$ 10-8) and suggested that the cumulative effect of multiple common variants contributes to polygenic dyslipidemia. The Ala54Thr polymorphism in the fatty acid-binding protein 2 (FABP2) gene as well as the T-455C and $\mathrm{C}-482 \mathrm{~T}$ polymorphisms in the apolipoprotein C-III (APOC3) gene promoter have been associated with features of the MetS in specific populations [80]. An interaction of the hepatic lipase (HL) promoter polymorphism with lipid-lowering medications in determining the level of HL activity has been also reported [81].
Low HDL-C was shown to be the most common metabolic abnormality in both sexes in studies done in Iran and Oman $[5,82]$. Among Iranian adolescents, low serum HDL and high serum triglyceride were the most common components of the MetS [83]. The prevalence of total hypercholesterolemia (TC $\geq 200 \mathrm{mg} / \mathrm{dl}$ ) and hypertriglyceridemia ( $\mathrm{TG} \geq 150 \mathrm{mg} / \mathrm{dl}$ ) was estimated to be $42.9 \%$ (45.4\% in females and $40.4 \%$ in males) and $36.4 \%$ among Iranian adults (33.2\% in females and $39.6 \%$ in males) in 2007 , respectively [51]. In Saudi Arabia the prevalence of hypertriglycemia was $40.3 \%$ (47.6\% in males, $33.7 \%$ in females) [84] and hypercholesterolemia was $54 \%$ (54.9\% among males and $53.2 \%$ for females) [84]. In a Turkish study, low HDL-C and hypertriglyceridemia were present in $31.8 \%$ and $30.7 \%$ subjects diagnosed with MetS [56].

\section{Other risk factors}

Some research suggest that various factors such as rapid nutrition transition [1,85], rural-to-urban migration [1,7,86-89], increasingly sedentary occupations and life style such as smoking [6,90-93], and maternal-fetal factors [1] may influence the prevalence rate of the MetS and obesity. In one survey, it was revealed that a Mediterraneanstyle diet might play a role in reducing the inflammatory state and endothelial dysfunction associated with the MetS [94]. Moreover, the diet reduced the components of the syndrome and the overall prevalence of the MetS was reduced by approximately one half [94]. Additionally, it was found that the prevalence of diabetes, obesity, hypertension and MetS decreased with high educational levels [95-100].

Several studies demonstrated there are some diseases and conditions associated with higher incidence of the MetS. For instance, MetS was 9.1 times more likely to be present in subjects with obstructive sleep apnea, since this disease was independently associated with increased systolic and diastolic blood pressure, higher fasting insulin and triglyceride concentrations, decreased HDL cholesterol and increased cholesterol: HDL ratio which are the MetS risk factors [101]. Factors such as lower adiponectin concentration levels is strongly associated with the clinical phenotype of the MetS which may be useful factor for management of this syndrome [102]. In another survey, MetS was significantly more common in psoriatic patients after the age of 40 years while these patients also had a higher prevalence of hypertriglyceridaemia and abdominal obesity, whereas hyperglycaemia, arterial hypertension and high-density lipoprotein cholesterol plasma levels were similar [103]. The MetS is highly prevalent in US schizophrenia patients with the rate of $40.9 \%$ and $42.7 \%$, respectively using the NCEP and AHA derived criteria, higher among women which stand for more cardiovascular risk [104]. In women with PCOS, the prevalence of the MetS and its components are more common leading to higher risk for cardiovascular disease [105].

Although there is evidence available in humans indicating that dietary fat quality influences metabolic abnormalities [106], the relation between nutrition, MetS, and atherosclerosis is complicated and intriguing [107].

Systemic responses to exposure to environmental chemical factors could potentially increase the risk of obesity [108], metabolic syndrome and insulin resistance [109], hypertension and nonalcoholic fatty liver diseases [110]. Harmful air pollutants lead to cardiovascular diseases such as artery blockages leading to heart attack and death of heart tissue due to oxygen deprivation, leading to permanent heart damage [111]. Moreover, impaired synthesis of hemoglobin and anemia, respiratory diseases, malignant disease, 
Citation: $\quad$ Nematy M , Ahmadpour F, Rassouli ZB, Ardabili HM, Azimi-Nezhad M (2014) A Review on Underlying Differences in the Prevalence of Metabolic Syndrome in the Middle East, Europe and North America. J Mol Genet Med S1: 019. doi:10.4172/1747-0862.S1-019

Page 5 of 12

hypertension, kidney damage, miscarriages and premature infants, nervous system disorders, brain damage, male infertility, loss of learning and behavioral disorders in children are from the negative effects of high concentrations of the air pollution in the body [111].

While some researchers suggest that hemodynamic, hepatic, inflammatory and psychological factors, microalbuminuria, prothrombotic and proinflammatory state in combination with the race and ethnicity are associated with the MetS prevalence $[6,50,112-118]$, greater efforts are needed to investigate the score of each one as a risk factor of MetS.

\begin{tabular}{|c|c|c|c|c|c|}
\hline Author and year & Country/region & Age (yr) & $\begin{array}{l}\text { Sample (n) } \\
\text { Men /Women }\end{array}$ & $\begin{array}{l}\text { Criterion } \\
\text { diagnosis }\end{array}$ & $\begin{array}{l}\text { Prevalence }(\%) \\
\text { Male/Female }\end{array}$ \\
\hline $\begin{array}{l}\text { Sarrafzadegan et al. } 2008 \text { [130] } \\
\text { Delavari et al. } 2009 \text { [136] }\end{array}$ & $\begin{array}{l}\text { Iran, urban and rural areas of } 3 \\
\text { cities in Iran. } \\
\text { Iran, urban and rural areas of } \\
\text { all } 30 \text { provinces }\end{array}$ & $\begin{array}{l}\geq 19 \\
25-64\end{array}$ & $\begin{array}{l}12,514 \text { adults } \\
3024\end{array}$ & $\begin{array}{l}\text { ATP III } \\
\text { ATP III } \\
\text { IDF } \\
\text { ATPIII/AHA/NHLBI }\end{array}$ & $\begin{array}{l}23.3 \\
10.735 .1 \\
34.7 \\
37.4 \\
41.6\end{array}$ \\
\hline Azizi et al. 2003 [5] & Iran, Capital, Tehran & $\geq 20$ & $\begin{array}{l}10,368 \text { of the adults } \\
4,397 / 5,971\end{array}$ & ATP III & $\begin{array}{l}30.1 \\
2442 \\
\text { age-standardized } \\
\text { prevalence: } \\
33.7\end{array}$ \\
\hline Delavar et al. 2009 [134] & Iran, North, Babol & $30-50$ & 984 women & ATP III & 31.0 \\
\hline Hashemi et al. 2012 [132] & Iran, South East, Zahedan & $\geq 19$ & $\begin{array}{l}1,802 \text { (735 men and } \\
1,067 \text { women) }\end{array}$ & $\begin{array}{l}\text { NCEP ATP III } \\
\text { IDF } \\
\text { IDF -AHA/NHLBI }\end{array}$ & $\begin{array}{l}15.424 .9 \\
20.028 .1 \\
19.725 .8\end{array}$ \\
\hline Azimi-Nezhad et al. 2009 [137] & Iran, East, Khorasan province & $15-65$ & $\begin{array}{l}2483 \text { men and } 2445 \\
\text { women }\end{array}$ & ATP III & 39.9 \\
\hline Sharifi et al. 2009 [138] & Iran, West, Zanjan & $>20$ & $\begin{array}{l}2941 \text { (1396 men and } \\
1545 \text { women) }\end{array}$ & ATP III & 23.124 .4 \\
\hline Mousavi et al. 2009[133] & Iran, Centre, Isfahan & $>20$ & 6,331 women & ATP III & 34.2 \\
\hline Kozan et al. 2006 [120] & $\begin{array}{l}\text { Turkey, urban and rural (seven } \\
\text { geographical regions) }\end{array}$ & $20-90$ & $\begin{array}{l}2,108 \text { men }(1,372 \text { in } \\
\text { urban and } 736 \text { in rural } \\
\text { areas }) \text { and } 2,151 \text { women } \\
(1,423 \text { in urban and } 728 \\
\text { in rural areas }\end{array}$ & ATP III & $\begin{array}{l}33.9 \\
2839.6\end{array}$ \\
\hline Sanisoglu et al. 2006 [100] & $\begin{array}{l}\text { Turkey, in the } \\
\text { seven main different regions }\end{array}$ & $>30$ & 15,468 & - & $\begin{array}{l}17.91 \\
10.0927 .33\end{array}$ \\
\hline Aboul Ella et al. 2010 [124] & Egypt & $10-18$ & 4250 & NCEP & 7.4 \\
\hline $\begin{array}{l}\text { Al-Daghri et al. } 2010 \text { [122] } \\
\text { Al-Daghri et al. } 2010 \text { [119] } \\
\text { Al-Nozha et al. } 2005 \text { [121] }\end{array}$ & Saudi Arabia & $\begin{array}{l}18-55 \\
10-18 \\
30-70\end{array}$ & $\begin{array}{l}2850 \\
1231 \\
17293\end{array}$ & $\begin{array}{l}\text { ATP-III } \\
\text { ATP-III } \\
\text { ATP-III }\end{array}$ & $\begin{array}{l}35.3 \\
9 \cdot 4 \\
39.3\end{array}$ \\
\hline Al-Isa et al. 2010 [139] & Kuwait & $10-19$ & 431 & $\begin{array}{l}\text { Modified ATP-III } \\
\text { IDF }\end{array}$ & $\begin{array}{l}9.1 \\
14.8\end{array}$ \\
\hline Al-Lawati et al. 2003 [81] & Oman & $\geq 20$ & 1419 & ATP-III & $\begin{array}{l}21 \\
19.523 .0\end{array}$ \\
\hline Malik et al. 2008 [123] & United Arab Emirates & $\geq 20$ & 4097 & $\begin{array}{l}\text { NCEP } \\
\text { IDF }\end{array}$ & $\begin{array}{l}39.6 \\
40.5\end{array}$ \\
\hline
\end{tabular}

\section{Epidemiology of the Metabolic Syndrome in the Middle East Countries} in developing countries. High prevalence of the MetS has been reported from the Middle East countries; Iran [119], Turkey [120], Saudi Arabia [121,122], and United Arab Emirate [123] (Table 2). The prevalence rates are also high in Egypt [124], Qatar [125], Jordan $[126,127]$ and Lebanon [128].
The MetS is increasing in line with the rising prevalence of obesity 
Citation: $\quad$ Nematy M , Ahmadpour F, Rassouli ZB, Ardabili HM, Azimi-Nezhad M (2014) A Review on Underlying Differences in the Prevalence of Metabolic Syndrome in the Middle East, Europe and North America. J Mol Genet Med S1: 019. doi:10.4172/1747-0862.S1-019

Page 6 of 12

\begin{tabular}{|l|l|l|l|l|l|}
\hline Bener et al. 2009 [125] & Qatar & $\geq 20$ & 1496 & $\begin{array}{l}\text { NCEP ATP III } \\
\text { IDF }\end{array}$ & $\begin{array}{l}26.5 \\
33.7\end{array}$ \\
\hline Loizou et al. 2006 [140] & Cyprus & $20-80$ & 1200 & NCEP ATP III & 22.2 \\
\hline $\begin{array}{l}\text { Khader et al. 2007 [126] } \\
\text { Khazale et al. 2007 [127] }\end{array}$ & Jordan & $\begin{array}{l}25 \\
32.5 \pm 7.2\end{array}$ & $\begin{array}{l}1121 \\
\text { Jordanians northern } \\
111 \text { Royal Jordanian Air } \\
\text { Force pilots }\end{array}$ & $\begin{array}{l}\text { ATP III } \\
\text { NCEP ATP III }\end{array}$ & 36.3 \\
18 (age adjusted)
\end{tabular}

Table 2: Prevalence of the metabolic syndrome in Iran and Middle East countries.

There is a paucity of data on prevalence of the MetS from other Middle East countries: Kuwait, Omani, Cyprus, Bahrain, Syria, Yemen, Iraq, and Palestine.

In a study done among Iranian adults, the overall prevalence of the MetS was $32.1 \%, 33.2 \%$ and $18.4 \%$ according to IDF, ATP III and WHO, respectively [129]. The result of another Iranian survey indicated the higher prevalence of the MetS in women, in urban areas, and in the 55- to 64-year age-group compared with the prevalence in men, in rural areas, and in other age-groups, respectively by NCEP/ATP III, IDF and modified ATP III/AHA/NHLBI definitions $[119,130]$. High socioeconomic status of family, medical history of parents and dietary habits were influencing factors in the prevalence of the MetS in Iran [131]. Furthermore, the prevalence is higher in Iranian women compared with men $[5,130,132]$.

The MetS was estimated to affect $>11$ million Iranians [119]. Agestandardized prevalence of the MetS in Tehran -the capital of Iranwas reported to be $33.7 \%$ ( $24 \%$ in men and $42 \%$ in women) [5]. Using ATP III criteria, the prevalence of the syndrome in other cities of Iran was $34.2 \%$ and $31 \%$ in women of Isfahan [133] and Babol [134], respectively. On the other hand, Zahedan (a southeastern city of Iran) showed lower prevalence of MetS: $21.0 \%$ (15.4\% in male, $24.9 \%$ female) using NCEP, ATP III criteria [132].

Different studies reported a considerably high prevalence of the MetS among Iranian youth [10]. Among 622 high school girls in Mashhad aged 15-17, the prevalence was $6.5 \%$ and increased to $45.1 \%$ in obese subjects [131]. Also there was $10.1 \%$ prevalence among 3,036 boys and girls in Tehran [83].

In a Turkish study, the prevalence of obesity and MetS was shown to be high (35.08\% and $17.91 \%$ respectively), particularly among women, but the prevalence of hypertension and hypercholesterolemia was relatively low in Turkish people [100]. Although another study reported a higher prevalence of the MetS in Turkish adults $(27 \%$ in men and $38.6 \%$ in women) [135]. The overall prevalence of MetS in a Qatari population was $26.5 \%$ and $33.7 \%$ according to ATP III and IDF criteria, more common among women [125]. Age and BMI were important significant contributors for MetS while the prevalence decreased with higher education and physical activity [125]. Among an adult Lebanese population, the overall prevalence of the MetS was $31.2 \%$ and was significantly higher in men than women [128]. Abdominal obesity, low HDL-C, Lack of physical exercise were the factors significantly associated with the overall prevalence of MetS [128].

In Egypt, the prevalence of the MetS is considerable among adolescents (with overall prevalence of $7.4 \%$ ), particularly among obese participants [124], which is in line with Iranian's prevalence rate. Family history of obesity and diabetes mellitus significantly increased the prevalence of MetS significantly as well as inactivity [124]. The prevalence of the MetS manifestations among Arab children is extremely high and dyslipidemia is the most common MetS abnormality [119,136-140].

\section{Prevalence of Metabolic Syndrome in Some of European and American Countries}

In most countries, between $20 \%$ and $30 \%$ of the adult population can be characterized as having the MetS and it is even higher in some populations or segments of the population $[39,141]$. With increasing affluence and aging of the population, the prevalence rises undoubtedly [141].

In a cohort study done among European youth, the prevalence of MetS was $0.2 \%$ and $1.4 \%$ in 10 - and 15 -y-olds, respectively [142]. They declared that some factors like high maternal BMI, low levels of cardiorespiratory fitness and physical activity independently contribute to the MetS and small increases in physical activity may significantly diminish the risk of MetS in healthy children [142].

A study based on 11 prospective European cohort studies, reported that the overall prevalence of the MetS was slightly higher in nondiabetic adult men (15.7\%) than in women (14.2\%) and these groups have an increased risk of death from all causes as well as cardiovascular disease [143]. The prevalence rates of MetS in different European and American countries have been shown in Table 3 (Figure $1)$.

\begin{tabular}{|l|l|l|l|l|l|}
\hline $\begin{array}{l}\text { Prevalence (\%) } \\
\text { Male Female }\end{array}$ & $\begin{array}{l}\text { Criterion for } \\
\text { diagnosis }\end{array}$ & $\begin{array}{l}\text { Sample }(\mathbf{n}) \\
\text { Men Women }\end{array}$ & Age (yr) & Country & Author and year \\
\hline $\begin{array}{l}\text { the syndrome frequencies increased to } \\
16 \% \text { in men and } 11 \% \text { in women (10\% and } \\
7 \% \text { at baseline) }\end{array}$ & NCEP & $\begin{array}{l}21092184 \\
\text { (from the D.E.S.I.R. } \\
\text { longitudinal cohort study) }\end{array}$ & $30-64$ & France & Balkau et al. 2003 [146] \\
\hline $5.9 \%$ in men and 2.1\% in women at t0 & NCEP ATP III & 1366 & $\begin{array}{l}371 \text { apparently } \\
\text { healthy families }\end{array}$ & France & $\begin{array}{l}\text { Maumus et al. 2005 } \\
{[147]}\end{array}$ \\
\hline
\end{tabular}


Citation: $\quad$ Nematy M , Ahmadpour F, Rassouli ZB, Ardabili HM, Azimi-Nezhad M (2014) A Review on Underlying Differences in the Prevalence of Metabolic Syndrome in the Middle East, Europe and North America. J Mol Genet Med S1: 019. doi:10.4172/1747-0862.S1-019

Page 7 of 12

\begin{tabular}{|c|c|c|c|c|c|}
\hline rising to $7.2 \%$ and $5.4 \%$ at $t+5$ & & $\begin{array}{l}\text { (from the STANISLAS } \\
\text { cohort) }\end{array}$ & & & \\
\hline $\begin{array}{l}\text { From } 1999 \text { to } 2002 \text {, the prevalence of } \\
\text { MetS increased from } 11.0 \% \text { to } 12.8 \% \text { in } \\
\text { men and from } 7.2 \% \text { to } 8.8 \% \text { in women }\end{array}$ & NCEP-ATP III & 62000 & $\geq 40$ & France & Guize et al. 2006 [112] \\
\hline $\begin{array}{l}4.8 \% \text { among participants aged } 19- \\
29 \text { years and } 43 \% \text { for participants over } \\
70 \text { years old }\end{array}$ & NCEP ATP III & 4153 & $\geq 18$ & Greece & Athyros et al. 2005 [148] \\
\hline $\begin{array}{l}17 \\
\text { (age/sex standardized) }\end{array}$ & NCEP ATP III & 809 & $35-74$ & $\begin{array}{l}\text { Spain, province } \\
\text { of Segovia }\end{array}$ & $\begin{array}{l}\text { Martinez-Larrad et al. } \\
2005[149]\end{array}$ \\
\hline 10.2 & modified ATP-III & $\begin{array}{l}7256 \text { active Spanish } \\
\text { working population } \\
(82.4 \% \text { male })\end{array}$ & $\begin{array}{l}\text { mean age (SD): } \\
45.4\end{array}$ & Spain & Alegría et al. 2005 [150] \\
\hline $\begin{array}{l}\text { Prevalence of metabolic syndrome } 31 \% \\
\text { and metabolic premorbid syndrome } 24 \%\end{array}$ & \begin{tabular}{lr}
\multicolumn{2}{l}{ harmonized definition } \\
and the new World \\
Health & Organization \\
proposal & (metabolic \\
premorbid syndrome)
\end{tabular} & 24670 & $35-74$ & Spain & $\begin{array}{l}\text { Fernández-Bergés et al. } \\
\text { 2012[151] }\end{array}$ \\
\hline $18 \%$ in women and $15 \%$ in men & NCEP ATP III & 2100 & $\geq 19$ & $\begin{array}{l}\text { Italy, } \\
\text { Lucca area }\end{array}$ & Miccoli et al. 2005 [152] \\
\hline $\begin{array}{l}29.6 \\
25.9\end{array}$ & $\begin{array}{l}\text { IDF } \\
2005 \text { ATP III }\end{array}$ & 10206 & $20-89$ & Norway & Hildrum et al. 2007 [13] \\
\hline $\begin{array}{l}11.519 .8 \\
13.720 .6 \\
11.023 .1\end{array}$ & $\begin{array}{l}\text { NCEP/ATP III } \\
\text { AHA/NHLBI } \\
\text { IDF }\end{array}$ & 3705 & $18-90$ & $\begin{array}{l}\text { Northwest } \\
\text { Russia, } \\
\text { Arkhangelsk }\end{array}$ & $\begin{array}{l}\text { Sidorenkov } O \text { et al. } \\
\text { 2010[12] }\end{array}$ \\
\hline $\begin{array}{l}23.7 \\
\text { (age-adjusted) }\end{array}$ & ATP III & 8814 & $\geq 20$ & US & Ford et al. 2002 [84] \\
\hline $22.6 \%$ in women and $22.8 \%$ in men & ATP III & 12861 & $\geq 20$ & US & Park et al. 2003 [6] \\
\hline $\begin{array}{l}34.5 \\
39\end{array}$ & $\begin{array}{l}\text { NCEP } \\
\text { IDF }\end{array}$ & 3601 & $\geq 20$ & US & Ford et al. 2005 [145] \\
\hline 34 & NCEP ATP III & $\begin{array}{lc}3,423 & \text { adults } \\
\text { NHANES } & \text { 2003-2006 }\end{array}$ & $\geq 20$ & US & Ervin et al. 2009 [113] \\
\hline 19.1 & ATP III & 1800 & $\geq 18$ & Canada & $\begin{array}{lll}\begin{array}{l}\text { Riediger } \\
2011[153]\end{array} & \text { et } \quad \text { al., }\end{array}$ \\
\hline
\end{tabular}

Table 3: Prevalence of the metabolic syndrome in some European and American countries.

Several studies have been performed in US reporting the prevalence of the MetS $[6,85,144,145]$. In a study done by Park et al. [6], the MetS was present in $22.8 \%$ and $22.6 \%$ of US men and women, respectively which varies substantially by ethnicity and several potentially modifiable lifestyle factors. For instance, older age, postmenopausal status, Mexican American ethnicity, higher body mass index, current smoking, low household income, high carbohydrate intake, no alcohol consumption, and physical inactivity were associated with increased odds of the MetS [6]. Increases in high blood pressure, waist circumference, and hypertriglyceridemia accounted for an increase in the prevalence of the MetS, particularly among women in another US study [144]. The use of the IDF definition of the MetS leads to a higher prevalence estimate of the MetS than the estimate based on the NCEP definition in the US $(39.0 \pm 1.1 \%$ vs. $34.5 \pm 0.9 \%)$ [145].

In a French cohort study, the age-specific frequency of the MetS is more than 2.5 times higher than in US and this ratio increased with age [146]. In another French study, Mets was associated with other hemodynamic, hepatic, inflammatory and psychological risk factors, and with a $70 \%$ increase in all-cause mortality [112].

Azimi-Nezhad et al. [18] investigated the difference in the prevalence of MetS between an Iranian and a French population. According to ATP III the prevalence of MetS was significantly higher in Iranian women $(55.0 \%)$, followed by Iranian men $(30.1 \%)$, than in French men (13.7\%) and French women (6.6\%), among 1,386 French and 1,194 Iranian adults. High prevalence of low HDL-C concentrations in the Iranian population, especially in Iranian women, compared with French women was the main finding of the study. 


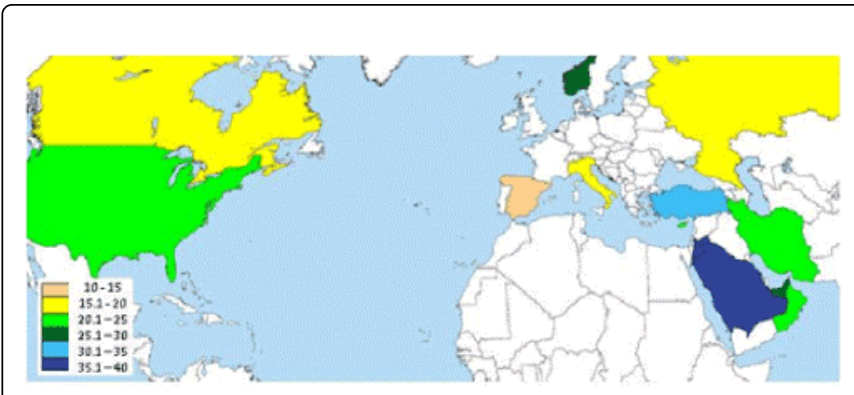

Figure 1: The prevalence of metabolic syndrome in the Middle East, Europe and North America (\%)

\section{Conclusion and Suggestions}

Prevalence of the MetS and its components has shown a rapid rise in developing countries in the past few decades leading to increased risk of CVD and consequent morbidity and mortality. For this reason, there is an urgent need to develop better approaches in order to prevent and manage the syndrome and strike at the underlying causes.

The pattern of the components of metabolic syndrome varies in the Middle East region in comparison with Europe and North America. In addition to differences of diet behaviors, the genetic factors and some of geographic dependent elements may influence the variation of metabolic syndrome architecture worldwide particularly in the Middle East region. Therefore, the study of differences between for example; gastrointestinal microbiomes and obviously the regional prevalent nutro-microorganisms, the European people and Middle Eastern individuals is recommended.

Both genetic and environmental factors seem to contribute to MetS prevalence. Studies have shown that genetic factors play a significant role in the prevalence of MetS risk factors. It is suggested that sensitivity of individuals to changes in body fat are genotypedependent. Also insulin resistance and type 2 diabetes mellitus (NIDDM) are multi-factorial in origin with both genetic and environmental factors contributing to their development. Moreover, the intersection of both lipid abnormalities and hypertension involving some of genetic and environmental factors is of special interest in some families. Genetic component also affects the individual habitual physical activity level by some indications and the propensity toward being spontaneously active could be partly influenced by the genotype.

As populations differ in prevalence of many complex genetic diseases which are probably influenced by the level of gene expression [154-158], we suggest that more researches should be done on allele frequency differences at regulatory polymorphisms which may account for some differences in prevalence of MetS.

\section{References}

1. Misra A, Khurana L (2008) Obesity and the metabolic syndrome in developing countries. J Clin Endocrinol Metab 93: S9-S30.

2. Misra A, Singhal N, Khurana L (2010) Obesity, the metabolic syndrome, and type 2 diabetes in developing countries: role of dietary fats and oils. J Am Coll Nutr 29: 289S-301S.

3. Monteiro CA, Moura EC, Conde WL, Popkin BM (2004) Socioeconomic status and obesity in adult populations of developing countries: a review. Bull World Health Organ 82: 940-946.
4. Popkin BM, Adair LS, Ng SW (2012) Global nutrition transition and the pandemic of obesity in developing countries. Nutr Rev 70: 3-21.

5. Azizi F, Salehi P, Etemadi A, Zahedi-Asl S (2003) Prevalence of metabolic syndrome in an urban population: Tehran Lipid and Glucose Study. Diabetes Res Clin Pract 61: 29-37.

6. Park YW, Zhu S, Palaniappan L, Heshka S, Carnethon MR, et al. (2003) The metabolic syndrome: prevalence and associated risk factor findings in the US population from the Third National Health and Nutrition Examination Survey, 1988-1994. Arch Intern Med 163: 427-436.

7. Després JP, Lemieux I (2006) Abdominal obesity and metabolic syndrome. Nature 444: 881-887.

8. Tan CE, Ma S, Wai D, Chew SK, Tai ES (2004) Can we apply the National Cholesterol Education Program Adult Treatment Panel definition of the metabolic syndrome to Asians? Diabetes care 27: 1182-1186.

9. Abdul-Rahim HF, Husseini A, Bjertness E, Giacaman R, Gordon NH, et al. (2001) The metabolic syndrome in the West Bank population: an urban-rural comparison. Diabetes Care 24: 275-279.

10. Kelishadi R (2007) Childhood overweight, obesity, and the metabolic syndrome in developing countries. Epidemiol Rev 29: 62-76.

11. Misra A, Vikram NK (2004) Insulin resistance syndrome (metabolic syndrome) and obesity in Asian Indians: evidence and implications. Nutrition 20: 482-491.

12. Sidorenkov O, Nilssen O, Brenn T, Martiushov S, Arkhipovsky VL, et al. (2010) Prevalence of the metabolic syndrome and its components in Northwest Russia: the Arkhangelsk study. BMC Public Health 10: 23.

13. Hildrum B, Mykletun A, Hole T, Midthjell K, Dahl AA (2007) Agespecific prevalence of the metabolic syndrome defined by the International Diabetes Federation and the National Cholesterol Education Program: the Norwegian HUNT 2 study. BMC Public Health 7: 220 .

14. Francke S, Manraj M, Lacquemant C, Lecoeur C, Leprêtre F, et al. (2001) A genome-wide scan for coronary heart disease suggests in IndoMauritians a susceptibility locus on chromosome $16 \mathrm{p} 13$ and replicates linkage with the metabolic syndrome on 3q27. Hum Mol Genettics 10: 2751-2765.

15. Sookoian S, Gemma C, Gianotti TF, Burgueño A, Castaño G, et al. (2008) Genetic variants of Clock transcription factor are associated with individual susceptibility to obesity. Am J Clin Nutr 87: 1606-1615.

16. Grundy SM, Hansen B, Smith SC Jr, Cleeman JI, Kahn RA, et al. (2004) Clinical management of metabolic syndrome report of the American Heart Association/National Heart, Lung, and Blood Institute/American Diabetes Association conference on scientific issues related to management. Arterioscler Thromb Vasc Biol 24: e19-e24.

17. Yamada Y, Kato K, Hibino T, Yokoi K, Matsuo H, et al. (2007) Prediction of genetic risk for metabolic syndrome. Atherosclerosis 191: 298-304.

18. Azimi-Nezhad M, Herbeth B, Siest G, Dadé S, Ndiaye NC, et al. (2012) High prevalence of metabolic syndrome in Iran in comparison with France: what are the components that explain this? Metabolic syndrome and related disorders 10: 181-188.

19. Grundy SM, Brewer Jr HB, Cleeman JI, Smith Jr SC, Lenfant C, et al. (2004) Definition of metabolic syndrome report of the National Heart, Lung, and Blood Institute/American Heart Association Conference on scientific issues related to definition. Circulation 109: 433-438.

20. Zimmet P, Magliano D, Matsuzawa Y, Alberti G, Shaw J (2005) The metabolic syndrome: a global public health problem and a new definition. J Atheroscler Thromb 12: 295-300.

21. Kelley DS, Adkins Y, Woodhouse LR, Swislocki A, Mackey BE, et al. (2012) Docosahexaenoic acid supplementation improved lipocentric but not glucocentric markers of insulin sensitivity in hypertriglyceridemic men. Metab Syndr Relat Disord 10: 32-38.

22. Alberti KG, Zimmet P, Shaw J (2006) Metabolic syndrome--a new worldwide definition. A Consensus Statement from the International Diabetes Federation. Diabet Med 23: 469-480. 
Citation: $\quad$ Nematy M , Ahmadpour F, Rassouli ZB, Ardabili HM, Azimi-Nezhad M (2014) A Review on Underlying Differences in the Prevalence of Metabolic Syndrome in the Middle East, Europe and North America. J Mol Genet Med S1: 019. doi:10.4172/1747-0862.S1-019

Page 9 of 12

23. Lorenzo C (2007) The National Cholesterol Education Program-Adult Treatment Panel III, International Diabetes Federation, and World Health Organization definitions of the metabolic syndrome as predictors of incident cardiovascular disease and diabetes. Diabetes care 30: 8-13.

24. Consultation W (1999) Definition, diagnosis and classification of diabetes mellitus and its complications. Geneva, Switzerland: World Health Organization 31: 1-59.

25. DeFronzo RA, Tobin JD, Andres R (1979) Glucose clamp technique: a method for quantifying insulin secretion and resistance. American Journal of Physiology-Endocrinology And Metabolism 237: E214.

26. Ferrannini E1, Natali A, Bell P, Cavallo-Perin P, Lalic N, et al. (1997) Insulin resistance and hypersecretion in obesity. European Group for the Study of Insulin Resistance (EGIR). J Clin Invest 100: 1166-1173.

27. Cleeman J (2001) Expert panel on Detection, Evaluation and Treatment of High blood Cholesterol in Adults. Executive Summary of the Third Report of the National Cholesterol Education Program (NCEP) Adult Treatment Panel (ATP III). Jama 285: 2486-2497.

28. Einhorn D (2003) American College of Endocrinology position statement on the insulin resistance syndrome. Endocrine practice: official journal of the American College of Endocrinology and the American Association of Clinical Endocrinologists 9: 237.

29. Lemieux I (2000) Hypertriglyceridemic Waist A Marker of the Atherogenic Metabolic Triad (Hyperinsulinemia; Hyperapolipoprotein B; Small, Dense LDL) in Men? Circulation 102: 179-184.

30. Galal O (2003) Nutrition-related health patterns in the Middle East. Asia Pac J Clin Nutr 12: 337-343.

31. Miranda PJ1, DeFronzo RA, Califf RM, Guyton JR (2005) Metabolic syndrome: definition, pathophysiology, and mechanisms. Am Heart J 149: 33-45.

32. Grundy SM, Brewer HB Jr, Cleeman JI, Smith SC Jr, Lenfant C, American Heart Association; National Heart, et al. (2004) Definition of metabolic syndrome: Report of the National Heart, Lung, and Blood Institute/American Heart Association conference on scientific issues related to definition. Circulation 109: 433-438.

33. Alberti K (1998)Report of the expert committee on the diagnosis and classification of diabetes mellitus. Diabetes Care 21: S5.

34. DeFronzo RA, Bonadonna RC, Ferrannini E (1992) Pathogenesis of NIDDM. A balanced overview. Diabetes Care 15: 318-368.

35. Hu FB, Manson JE, Stampfer MJ, Colditz G, Liu S, et al. (2001) Diet, lifestyle, and the risk of type 2 diabetes mellitus in women. $\mathrm{N}$ Engl J Med 345: 790-797.

36. Ritchie SA, Connell JM (2007) The link between abdominal obesity, metabolic syndrome and cardiovascular disease. Nutr Metab Cardiovasc Dis 17: 319-326.

37. Carr DB, Utzschneider KM, Hull RL, Kodama K, Retzlaff BM, et al. (2004) Intra-abdominal fat is a major determinant of the National Cholesterol Education Program Adult Treatment Panel III criteria for the metabolic syndrome. Diabetes 53: 2087-2094.

38. Brochu M, Starling RD, Tchernof A, Matthews DE, Garcia-Rubi E, et al. (2000) Visceral adipose tissue is an independent correlate of glucose disposal in older obese postmenopausal women. J Clin Endocrinol Metab 85: 2378-2384.

39. Abate N, Garg A, Peshock RM, Stray-Gundersen J, Adams-Huet B, et al. (1996) Relationship of generalized and regional adiposity to insulin sensitivity in men with NIDDM. Diabetes 45: 1684-1693.

40. Goodpaster BH, Thaete FL, Simoneau JA, Kelley DE (1997) Subcutaneous abdominal fat and thigh muscle composition predict insulin sensitivity independently of visceral fat. Diabetes 46: 1579-1585.

41. Abate N, Garg A, Peshock RM, Stray-Gundersen J, Grundy SM (1995) Relationships of generalized and regional adiposity to insulin sensitivity in men. J Clin Invest 96: 88-98.

42. Kelley DE, Thaete FL, Troost F, Huwe T, Goodpaster BH (2000) Subdivisions of subcutaneous abdominal adipose tissue and insulin resistance. Am J Physiol Endocrinol Metab 278: E941-948.
43. Bouchard C (1989) Genetic factors in obesity. Med Clin North Am 73: 67-81.

44. Schadt EE (2003)Genetics of gene expression surveyed in maize, mouse and man. Nature 422: 297-302.

45. Comuzzie AG, Funahashi T, Sonnenberg G, Martin LJ, Jacob HJ, et al. (2001) The genetic basis of plasma variation in adiponectin, a global endophenotype for obesity and the metabolic syndrome. J Clin Endocrinol Metab 86: 4321-4325.

46. Maes HH, Neale MC, Eaves LJ (1997) Genetic and environmental factors in relative body weight and human adiposity. Behav Genet 27: 325-351.

47. Herbert A, Gerry NP, McQueen MB, Heid IM, Pfeufer A, et al. (2006) A common genetic variant is associated with adult and childhood obesity. Science 312: 279-283.

48. Widén E, Lehto M, Kanninen T, Walston J, Shuldiner AR, et al. (1995) Association of a polymorphism in the beta 3-adrenergic-receptor gene with features of the insulin resistance syndrome in Finns. N Engl J Med 333: 348-351.

49. Farooqi IS, O'Rahilly S (2007) Genetic factors in human obesity. Obes Rev 8 Suppl 1: 37-40.

50. Sliem HA, Ahmed S, Nemr N, El-Sherif I (2012) Metabolic syndrome in the Middle East. Indian J Endocrinol Metab 16: 67-71.

51. Esteghamati A, Meysamie A, Khalilzadeh O, Rashidi A, Haghazali M, et al. (2009) Third national Surveillance of Risk Factors of NonCommunicable Diseases (SuRFNCD-2007) in Iran: methods and results on prevalence of diabetes, hypertension, obesity, central obesity, and dyslipidemia. BMC Public Health 9: 167.

52. Rashidi A, Mohammadpour-Ahranjani B, Vafa MR, Karandish M (2005) Prevalence of obesity in Iran. Obes Rev 6: 191-192.

53. Al-Nuaim AR (1996)High prevalence of overweight and obesity in Saudi Arabia. International journal of obesity and related metabolic disorders. J Int Asso Study Obes 20: 547-552.

54. Al-Lawati JA, Jousilahti PJ (2004) Prevalence and 10-year secular trend of obesity in Oman. Saudi Med J 25: 346-351.

55. Sibai AM, Hwalla N, Adra N, Rahal B (2003) Prevalence and covariates of obesity in Lebanon: findings from the first epidemiological study. Obes Res 11: 1353-1361.

56. Erem C, Hacihasanoglu A, Deger O, TopbaÅŸ M, Hosver I, et al. (2008) Prevalence of metabolic syndrome and associated risk factors among Turkish adults: Trabzon MetS study. Endocrine 33: 9-20.

57. Grundy SM, Cleeman JI, Daniels SR, Donato KA, Eckel RH, et al. (2005) Diagnosis and management of the metabolic syndrome: an American Heart Association/National Heart, Lung, and Blood Institute Scientific Statement. Circulation 112: 2735-2752.

58. Franklin SS (2006) Hypertension in the metabolic syndrome. Metab Syndr Relat Disord 4: 287-298.

59. Duvnjak L, Bulum T, MetelkoZ (2008) Hypertension and the metabolic syndrome. Diabetologia Croatica 37: 83-89.

60. Kearney PM, Whelton M, Reynolds K, Muntner P, Whelton PK, et al. (2005) Global burden of hypertension: analysis of worldwide data. Lancet 365: 217-223.

61. Altun B, Arici M, NergizoÄŸlu G, Derici U, Karatan O, et al. (2005) Prevalence, awareness, treatment and control of hypertension in Turkey (the PatenT study) in 2003. J Hypertens 23: 1817-1823.

62. Erem C, Yildiz R, Kavgaci H, Karahan C, Deger O, et al. (2001) Prevalence of diabetes, obesity and hypertension in a Turkish population (Trabzon city). Diabetes Res Clin Pract 54: 203-208.

63. Al Riyami AA, Afifi MM (2002) Hypertension in Oman: distribution and correlates. J Egypt Public Health Assoc 77: 383-407.

64. Guthold R, Ono T, Strong KL, Chatterji S, Morabia A (2008) Worldwide variability in physical inactivity a 51-country survey. Am J Prev Med 34: 486-494.

65. Oldridge NB (2008) Economic burden of physical inactivity: healthcare costs associated with cardiovascular disease. Eur J Cardiovasc Prev Rehabil 15: 130-139. 
Citation: $\quad$ Nematy M , Ahmadpour F, Rassouli ZB, Ardabili HM, Azimi-Nezhad M (2014) A Review on Underlying Differences in the Prevalence of Metabolic Syndrome in the Middle East, Europe and North America. J Mol Genet Med S1: 019. doi:10.4172/1747-0862.S1-019

Page 10 of 12

66. Daryani A, Berglund L, Andersson A, Kocturk T, Becker W, et al. (2005) Risk factors for coronary heart disease among immigrant women from Iran and Turkey, compared to women of Swedish ethnicity. Ethn Dis 15: 213-220.

67. Al-Nozha MM, Al-Hazzaa HM, Arafah MR, Al-Khadra A, Al-Mazrou YY, et al. (2007) Prevalence of physical activity and inactivity among Saudis aged 30-70 years. A population-based cross-sectional study. Saudi Med J 28: 559-568.

68. Le Chatelier E, Nielsen T, Qin J, Prifti E, Hildebrand F, et al. (2013) Richness of human gut microbiome correlates with metabolic markers. Nature 500: 541-546.

69. Cotillard A, Kennedy SP, Kong LC, Prifti E, Pons N, et al. (2013) Dietary intervention impact on gut microbial gene richness. Nature 500: 585-588.

70. Kim BS, Jeon YS, Chun J (2013) Current status and future promise of the human microbiome. Pediatr Gastroenterol Hepatol Nutr 16: 71-79.

71. Ursell LK, Clemente JC, Rideout JR, Gevers D, Caporaso JG, et al. (2012) The interpersonal and intrapersonal diversity of human-associated microbiota in key body sites. J Allergy Clin Immunol 129: 1204-1208.

72. Ley RE, Turnbaugh PJ, Klein S, Gordon JI (2006) Microbial ecology: human gut microbes associated with obesity. Nature 444: 1022-1023.

73. Booth FW, Chakravarthy MV, Spangenburg EE (2002) Exercise and gene expression: physiological regulation of the human genome through physical activity. J Physiol 543: 399-411.

74. Arsenault BJ, Boekholdt SM, Kastelein JJ (2011) Lipid parameters for measuring risk of cardiovascular disease. Nat Rev Cardiol 8: 197-206.

75. Krauss RM (2005) Dietary and genetic probes of atherogenic dyslipidemia. Arterioscler Thromb Vasc Biol 25: 2265-2272.

76. Clarke R, Peden JF, Hopewell JC, Kyriakou T, Goel A, et al. (2009) Genetic variants associated with $\mathrm{Lp}(\mathrm{a})$ lipoprotein level and coronary disease. N Engl J Med 361: 2518-2528.

77. Hegele RA (2009) A polygenic basis for four classical Fredrickson hyperlipoproteinemia phenotypes that are characterized by hypertriglyceridemia. Human molecular genetics 18: 4189-4194.

78. Williams RR, Hunt SC, Hopkins PN, Wu LL, Hasstedt SJ, et al. (1993) Genetic basis of familial dyslipidemia and hypertension: 15-year results from Utah. Am J Hypertens 6: 319S-327S.

79. Kathiresan S, Willer CJ, Peloso GM, Demissie S, Musunuru K, et al (2009) Common variants at 30 loci contribute to polygenic dyslipidemia. Nat Genet 41: 56-65.

80. Guettier JM (2005)Polymorphisms in the fatty acid-binding protein 2 and apolipoprotein C-III genes are associated with the metabolic syndrome and dyslipidemia in a South Indian population. J Clin Endocrinol Meta 90: 1705-1711.

81. Deeb SS, Zambon A, Carr MC, Ayyobi AF, Brunzell JD (2003) Hepatic lipase and dyslipidemia: interactions among genetic variants, obesity, gender, and diet. J Lipid Res 44: 1279-1286.

82. Al-Lawati JA, Mohammed AJ, Al-Hinai HQ, Jousilahti P (2003) Prevalence of the metabolic syndrome among Omani adults. Diabetes Care 26: 1781-1785.

83. Esmaillzadeh A, Mirmiran P, Azadbakht L, Etemadi A, Azizi F (2006) High prevalence of the metabolic syndrome in Iranian adolescents. Obesity (Silver Spring) 14: 377-382.

84. Al-Nozha MM, Arafah MR, Al-Maatouq MA, Khalil MZ, Khan NB, et al. (2008) Hyperlipidemia in Saudi Arabia. Saudi Med J 29: 282-287.

85. Ford ES1, Giles WH, Dietz WH (2002) Prevalence of the metabolic syndrome among US adults: findings from the third National Health and Nutrition Examination Survey. JAMA 287: 356-359.

86. Grundy SM (2007) Metabolic syndrome: a multiplex cardiovascular risk factor. J Clin Endocrinol Metab 92: 399-404.

87. Prabhakaran D, Chaturvedi V, Shah P, Manhapra A, Jeemon P, et al. (2007) Differences in the prevalence of metabolic syndrome in urban and rural India: a problem of urbanization. Chronic Illn 3: 8-19.

88. Zimmet P, Alberti KG, Kaufman F, Tajima N, Silink M, et al. (2007) The metabolic syndrome in children and adolescents - an IDF consensus report. Pediatr Diabetes 8: 299-306.
89. Fezeu L (2007) Metabolic syndrome in a sub-Saharan African setting: Central obesity may be the key determinant. Atherosclerosis 193: 70-76.

90. Lakka TA, Laaksonen DE, Lakka HM, Männikkö N, Niskanen LK, et al. (2003) Sedentary lifestyle, poor cardiorespiratory fitness, and the metabolic syndrome. Med Sci Sports Exerc 35: 1279-1286.

91. Ferreira I, Twisk JW, van Mechelen W, Kemper HC, Stehouwer CD (2005) Development of fatness, fitness, and lifestyle from adolescence to the age of 36 years: determinants of the metabolic syndrome in young adults: the Amsterdam growth and health longitudinal study. Archives of internal medicine 165: 42

92. Panagiotakos DB1, Pitsavos C, Chrysohoou C, Skoumas J, Tousoulis D, et al. (2004) Impact of lifestyle habits on the prevalence of the metabolic syndrome among Greek adults from the ATTICA study. Am Heart J 147: 106-112.

93. Laaksonen DE, Lakka HM, Salonen JT, Niskanen LK, Rauramaa R, et al. (2002) Low levels of leisure-time physical activity and cardiorespiratory fitness predict development of the metabolic syndrome. Diabetes Care 25: 1612-1618.

94. Esposito K, Marfella R, Ciotola M, Di Palo C, Giugliano F, et al. (2004) Effect of a mediterranean-style diet on endothelial dysfunction and markers of vascular inflammation in the metabolic syndrome: a randomized trial. JAMA 292: 1440-1446.

95. Rosmond R, Björntorp P (1999) Psychosocial and socio-economic factors in women and their relationship to obesity and regional body fat distribution. Int J Obes Relat Metab Disord 23: 138-145.

96. [No authors listed] (2000) Obesity: preventing and managing the global epidemic. Report of a WHO consultation. World Health Organ Tech Rep Ser 894: i-xii, 1-253.

97. Martínez-Ros MT, Tormo MJ, Navarro C, Chirlaque MD, Pérez-Flores D (2001) Extremely high prevalence of overweight and obesity in Murcia, a Mediterranean region in south-east Spain. Int J Obes Relat Metab Disord 25: $1372-1380$

98. Stelmach W, Kaczmarczyk-Chå̊,as K, Bielecki W, Stelmach I, Drygas W (2004) How income and education contribute to risk factors for cardiovascular disease in the elderly in a former Communist country. Public Health 118: 439-449.

99. Erem C1, Arslan C, Hacihasanoglu A, Deger O, Topbas M, et al. (2004) Prevalence of obesity and associated risk factors in a Turkish population (trabzon city, Turkey). Obes Res 12: 1117-1127.

100. Sanisoglu SY, Oktenli C, Hasimi A, Yokusoglu M, Ugurlu M (2006) Prevalence of metabolic syndrome-related disorders in a large adult population in Turkey. BMC Public Health 6: 92.

101. Coughlin SR, Mawdsley L, Mugarza JA, Calverley PM, Wilding JP (2004) Obstructive sleep apnoea is independently associated with an increased prevalence of metabolic syndrome. Eur Heart J 25: 735-741.

102. Saari KM, Lindeman SM, Viilo KM, Isohanni MK, Järvelin MR, et al. (2005) A 4-fold risk of metabolic syndrome in patients with schizophrenia: the Northern Finland 1966 Birth Cohort study. J Clin Psychiatry 66: 559-563.

103. Gisondi P, Tessari G, Conti A, Piaserico S, Schianchi S, et al. (2007) Prevalence of metabolic syndrome in patients with psoriasis: a hospitalbased case-control study. Br J Dermatol 157: 68-73.

104. McEvoy JP, Meyer JM, Goff DC, Nasrallah HA, Davis SM, et al. (2005) Prevalence of the metabolic syndrome in patients with schizophrenia: baseline results from the Clinical Antipsychotic Trials of Intervention Effectiveness (CATIE) schizophrenia trial and comparison with national estimates from NHANES III. Schizophrenia research 80: 19-32.

105. Apridonidze T, Essah PA, Iuorno MJ, Nestler JE (2005) Prevalence and characteristics of the metabolic syndrome in women with polycystic ovary syndrome. J Clin Endocrinol Metab 90: 1929-1935.

106. Riccardi G, Giacco R, Rivellese AA (2004) Dietary fat, insulin sensitivity and the metabolic syndrome. Clin Nutr 23: 447-456.

107. Misra A (2002) Overnutrition and nutritional deficiency contribute to metabolic syndrome and atherosclerosis in Asian Indians. Nutrition 18: 702-703. 
Citation: $\quad$ Nematy M , Ahmadpour F, Rassouli ZB, Ardabili HM, Azimi-Nezhad M (2014) A Review on Underlying Differences in the Prevalence of Metabolic Syndrome in the Middle East, Europe and North America. J Mol Genet Med S1: 019. doi:10.4172/1747-0862.S1-019

Page 11 of 12

108. Kelishadi R, Poursafa P, Jamshidi F (2013) Role of environmental chemicals in obesity: a systematic review on the current evidence. J Environ Public Health 2013: 896789.

109. Kelishadi R, Mirghaffari N, Poursafa P, Gidding SS (2009) Lifestyle and environmental factors associated with inflammation, oxidative stress and insulin resistance in children. Atherosclerosis 203: 311-319.

110. Kelishadi R, Poursafa P (2011) Obesity and air pollution: global risk factors for pediatric non-alcoholic fatty liver disease. Hepat Mon 11: 794-802.

111. Rashidi M, Rameshat MH, Gharib H (2012) Air Pollution and Death Due to Cardiovascular Diseases (Case Study: Isfahan Province of Iran).

112. Guize L, Thomas F, Pannier B, Bean K, Danchin N, et al. (2006) [Metabolic syndrome: prevalence, risk factors and mortality in a French population of 62000 subjects]. Bull Acad Natl Med 190: 685-697.

113. Ervin RB (2009) Prevalence of metabolic syndrome among adults 20 years of age and over, by sex, age, race and ethnicity, and body mass index: United States, 2003-2006. Natl Health Stat Report : 1-7.

114. Smith SC Jr, Clark LT, Cooper RS, Daniels SR, Kumanyika SK, et al (2005) Discovering the full spectrum of cardiovascular disease: Minority Health Summit 2003: report of the Obesity, Metabolic Syndrome, and Hypertension Writing Group. Circulation 111: e134-139.

115. Goldbacher EM, Matthews KA (2007) Are psychological characteristics related to risk of the metabolic syndrome? A review of the literature. Ann Behav Med 34: 240-252.

116. Kinder LS, Carnethon MR, Palaniappan LP, King AC, Fortmann SP (2004) Depression and the metabolic syndrome in young adults: findings from the Third National Health and Nutrition Examination Survey. Psychosom Med 66: 316-322.

117. Räikkönen K, Matthews KA, Kuller LH (2002) The relationship between psychological risk attributes and the metabolic syndrome in healthy women: antecedent or consequence? Metabolism 51: 1573-1577.

118. Björntorp P, Rosmond R (2000) The metabolic syndrome--a neuroendocrine disorder? Br J Nutr 83 Suppl 1: S49-57.

119. Delavari A, Forouzanfar MH, Alikhani S, Sharifian A, Kelishadi R (2009) First Nationwide Study of the Prevalence of the Metabolic Syndrome and Optimal Cutoff Points of Waist Circumference in the Middle East: The National Survey of Risk Factors for Noncommunicable Diseases of Iran. Diabetes Care 32: 1092-1097.

120. Kozan O, Oguz A, Abaci A, Erol C, Ongen Z, et al. (2007) Prevalence of the metabolic syndrome among Turkish adults. Eur J Clin Nutr 61: 548-553.

121. Al-Nozha M, Al-Khadra A, Arafah MR, Al-Maatouq MA, Khalil MZ, et al. (2005) Metabolic syndrome in Saudi Arabia. Saudi Med J 26: 1918-1925.

122. Al-Daghri NM, Al-Attas OS, Alokail MS, Alkharfy KM, Sabico SL, et al. (2010) Decreasing prevalence of the full metabolic syndrome but a persistently high prevalence of dyslipidemia among adult Arabs. PLoS One 5: e12159.

123. Malik M, Razig SA (2008) The prevalence of the metabolic syndrome among the multiethnic population of the United Arab Emirates: a report of a national survey. Metab Syndr Relat Disord 6: 177-186.

124. Aboul Ella NA, Shehab DI, Ismail MA, Maksoud AA (2010) Prevalence of metabolic syndrome and insulin resistance among Egyptian adolescents 10 to 18 years of age. J Clin Lipidol 4: 185-195.

125. Bener A, Zirie M, Musallam M, Khader YS, Al-Hamaq AO (2009) Prevalence of metabolic syndrome according to Adult Treatment Panel III and International Diabetes Federation criteria: a population-based study. Metab Syndr Relat Disord 7: 221-230.

126. Khader Y, Bateiha A, El-Khateeb M, Al-Shaikh A, Ajlouni K (2007) High prevalence of the metabolic syndrome among Northern Jordanians. J Diabetes Complications 21: 214-219.

127. Khazale NS, Haddad F (2007) Prevalence and characteristics of metabolic syndrome in 111 Royal Jordanian Air Force pilots. Aviat Space Environ Med 78: 968-972.
128. Sibai AM, Obeidb O, Batalb M, Adrab N, Khouryb DE, et al. (2008) Prevalence and correlates of metabolic syndrome in an adult Lebanese population. CVD Prev Control 3: 83-90.

129. Zabetian A, Hadaegh F, Azizi F (2007) Prevalence of metabolic syndrome in Iranian adult population, concordance between the IDF with the ATPIII and the WHO definitions. Diabetes Res Clin Pract 77: 251-257.

130. Sarrafzadegan N, Kelishadi R, Baghaei A, Hussein Sadri G, Malekafzali H, et al. (2008) Metabolic syndrome: an emerging public health problem in Iranian women: Isfahan Healthy Heart Program. Int J Cardiol 131: 90-96.

131. Mirhosseini NZ, Yusoff NA, Shahar S, Parizadeh SM, Mobarhen MG, et al. (2009) Prevalence of the metabolic syndrome and its influencing factors among adolescent girls in Mashhad, Iran. Asia Pac J Clin Nutr 18: 131-136.

132. Kaykhaei M, Hashemi M, Narouie B, Shikhzadeh A, Jahantigh M, et al. (2012) Prevalence of metabolic syndrome in adult population from zahedan, southeast iran. Iran J Public Health 41: 70-76.

133. Mousavi E, Gharipour M, Tavassoli A, Sadri GH, Sarrafzadegan N (2009) Multiparity and risk of metabolic syndrome: Isfahan Healthy Heart Program. Metab Syndr Relat Disord 7: 519-524.

134. Delavar MA, Lye MS, Khor GL, Hanachi P, Hassan ST (2009) Prevalence of metabolic syndrome among middle aged women in Babol, Iran. Southeast Asian J Trop Med Public Health 40: 612-628.

135. Onat A, Ceyhan K, BaÅŸar O, Erer B, Toprak S, et al. (2002) Metabolic syndrome: major impact on coronary risk in a population with low cholesterol levels--a prospective and cross-sectional evaluation. Atherosclerosis 165: 285-292.

136. Al-Daghri NM (2010) Extremely high prevalence of metabolic syndrome manifestations among Arab youth: a call for early intervention. Eur J Clin Invest 40: 1063-1066.

137. Azimi-Nezhad M, Ghayour-Mobarhan M, Safarian M, Esmailee $H$ Parizadeh SM, et al. (2009) Anthropometric indices of obesity and the prediction of cardiovascular risk factors in an Iranian population. ScientificWorldJournal 9: 424-430.

138. Sharifi F, Mousavinasab SN, Saeini M, Dinmohammadi M (2009) Prevalence of metabolic syndrome in an adult urban population of the west of Iran. Exp Diabetes Res 2009: 136501.

139. Al-Isa A, Akanji AO, Thalib L (2010) Prevalence of the metabolic syndrome among female Kuwaiti adolescents using two different criteria. Br J Nutr 103: 77-81.

140. Loizou T, Pouloukas S, Tountas C, Thanopoulou A, Karamanos V (2006) An epidemiologic study on the prevalence of diabetes, glucose intolerance, and metabolic syndrome in the adult population of the Republic of Cyprus. Diabetes Care 29: 1714-1715.

141. Grundy SM (2008) Metabolic syndrome pandemic. Arterioscler Thromb Vasc Biol 28: 629-636.

142. Ekelund U, Anderssen S, Andersen LB, Riddoch CJ, Sardinha LB, et al. (2009) Prevalence and correlates of the metabolic syndrome in a population-based sample of European youth. Am J Clin Nutr 89: 90-96.

143. Hu G, Qiao Q, Tuomilehto J, Balkau B, Borch-Johnsen K, et al. (2004) Prevalence of the metabolic syndrome and its relation to all-cause and cardiovascular mortality in nondiabetic European men and women. Arch Intern Med 164: 1066-1076.

144. Ford ES, Giles WH, Mokdad AH (2004) Increasing prevalence of the metabolic syndrome among u.s. Adults. Diabetes Care 27: 2444-2449.

145. Ford ES (2005) Prevalence of the metabolic syndrome defined by the International Diabetes Federation among adults in the U.S. Diabetes Care 28: 2745-2749.

146. Balkau B, Vernay M, Mhamdi L, Novak M, Arondel D, et al. (2003) The incidence and persistence of the NCEP (National Cholesterol Education Program) metabolic syndrome. The French D.E.S.I.R. study. Diabetes Metab 29: 526-532.

147. Maumus, S, Marie B, Siest G, Visvikis-Siest S (2005) A Prospective Study on the Prevalence of Metabolic Syndrome Among Healthy French Families Two cardiovascular risk factors (HDL cholesterol and tumor 
Citation: $\quad$ Nematy M , Ahmadpour F, Rassouli ZB, Ardabili HM, Azimi-Nezhad M (2014) A Review on Underlying Differences in the Prevalence of Metabolic Syndrome in the Middle East, Europe and North America. J Mol Genet Med S1: 019. doi:10.4172/1747-0862.S1-019

Page 12 of 12

necrosis factor-a) are revealed in the offspring of parents with metabolic syndrome. Diabetes Care 28: 675-682.

148. Athyros VG, Bouloukos VI, Pehlivanidis AN, Papageorgiou AA, Dionysopoulou SG, et al. (2005) The prevalence of the metabolic syndrome in Greece: the MetS-Greece Multicentre Study. Diabetes Obes Metab 7: 397-405.

149. Martínez-Larrad MT, Fernández-Pérez C, González-Sánchez JL, López A, Fernández-Alvarez J, et al. (2005) Prevalence of the metabolic syndrome (ATP-III criteria). Population-based study of rural and urban areas in the Spanish province of Segovia]. Medicina Clin 125: 481-486.

150. Alegría E1, Cordero A, Laclaustra M, Grima A, León M, et al. (2005) [Prevalence of metabolic syndrome in the Spanish working population: MESYAS registry]. Rev Esp Cardiol 58: 797-806.

151. Fernández-Bergés D1, Cabrera de León A, Sanz H, Elosua R, Guembe MJ, et al. (2012) Metabolic syndrome in Spain: prevalence and coronary risk associated with harmonized definition and WHO proposal. DARIOS study. Rev Esp Cardiol (Engl Ed) 65: 241-248.

152. Miccoli R, Bianchi C, Odoguardi L, Penno G, Caricato F, et al. (2005) Prevalence of the metabolic syndrome among Italian adults according to ATP III definition. Nutr Metab Cardiovasc Dis 15: 250-254.
153. Riediger ND, Clara I (2011) Prevalence of metabolic syndrome in the Canadian adult population. CMAJ 183: E1127-1134.

154. Spielman RS, Bastone LA, Burdick JT, Morley M, Ewens WJ, et al. (2007) Common genetic variants account for differences in gene expression among ethnic groups. Nat Genet 39: 226-231.

155. Chakravarti A (1999) Population genetics--making sense out of sequence. Nat Genet 21: 56-60.

156. Adeyemo A, Rotimi C (2010) Genetic variants associated with complex human diseases show wide variation across multiple populations. Public Health Genomics 13: 72-79.

157. Cardon LR, Palmer LJ (2003) Population stratification and spurious allelic association. Lancet 361: 598-604.

158. Hirschhorn JN, Daly MJ (2005) Genome-wide association studies for common diseases and complex traits. Nat Rev Genet 6: 95-108.
This article was originally published in a special issue, entitled: "Molecular \&

Cellular Aspects in Obesity and Diabetes", Edited by Dr. Masayoshi

Yamaguchi, Emory University School of Medicine, USA 